\title{
Forest Spirits in the Udmurt Worldview
}

Tatiana Panina

e-mail: tipanina@mail.ru

\section{Tatiana Vladykina}

e-mail: tgvladykina@mail.ru

\begin{abstract}
Forest spirits are widely represented in the Udmurt traditional belief system. The present study is aimed at systematising traditional folk beliefs about the best-known mythological beings living in the woods, namely n'ulesmurt ('forest man'), palesmurt (lit: 'half-man'), and obyda ('forest woman'). The article provides a detailed description of the appearance of forest spirits, analyses their distinctive features and functions, and presents how beliefs about those mythological beings have evolved over the last centuries.
\end{abstract}

Keywords: forest spirits, n'ulesmurt, obyda, palesmurt, Udmurt mythology

\section{Introduction}

Forest spirits are widely represented in the Udmurt traditional belief system. The process of populating the forests with all kinds of supernatural agents is indubitably related to natural geographical features in the place the Udmurt inhabit and the activities they 
have been engaged in, for example hunting, an important means of livelihood for many centuries. The present study is aimed at systematising traditional folk beliefs about the best-known mythological beings living in the woods, namely n'ulesmurt (lit: 'forest man'), palesmurt (lit: 'half-man'), and obyda ('forest woman'). The study is based firstly on archive materials from the Udmurt Institute of History, Language and Literature, and the Institute for Udmurt Philology, Finno-Ugric Studies and Journalism at the Udmurt State University; secondly, on field data collected by the authors in different parts of the Udmurt Republic in the late $20^{\text {th }}$ and early $21^{\text {st }}$ centuries; and, finally, on various pieces of published research about Udmurt traditional culture. Comprehensive data including descriptive details of the forest spirits and unique folklore texts were collected by Russian and foreign researchers of the late $19^{\text {th }}$ and early $20^{\text {th }}$ centuries (for example, Yrjö Wichmann, Bernát Munkácsi, Nikolay Pervukhin, Grigoriy Vereshchagin, Uno Holmberg). As for contemporary studies by ethnographers and folklorists, not only do they provide some generalising characteristics of mythological beings and forms of worship, they also introduce new field records into scientific discourse (Vladykin 1994: 97; Shutova 2001: 95-96, 237-238; Vladykina 2009; Vladykina, Panina 2015; Panina 2017). Unique folklore and ethnographic data can also be found in dialectal collections of transcribed Udmurt texts published by linguists (Kel'makov 1981; Karpova 2005).

When conducting this research we adopted both synchronous and diachronic approaches. The article provides a detailed description of the forest spirits' appearance, analyses their distinctive features and functions, and presents how the beliefs about these mythological beings have evolved over the last centuries. 


\section{N'ulesmurt, 'forest man'}

Today n'ulesmurt, 'forest man', is unambiguously considered the main mythological being, who acts as a keeper and warden of the woodland. Depending on local traditions, this creature is also known by other names, such as tshatshtshamurt ('forest man'), n'ulesn'un'a ('forest father/uncle'), bydzh'ym n'un'a ('great father/ uncle'), n'uleskuz'o / tshatshtshakoz'ain ('forest master'), l'eshak (a Russian borrowing, one of the name variations of leshiy).

The forest spirit analysed here is believed to be invisible to the human eye in most cases, although it invariably appears before those who break any taboo. In folk tales, a person first hears a sudden loud noise and only then sees the spirit itself. In physical appearance it resembles a human being, generally an elderly man. However, it is able to change shape depending on the circumstances: in a forest it is as tall as the trees, in a meadow as short as the grass, and in a crowd a bit taller than people. If n'ulesmurt likes a person it looks like an ordinary man, otherwise it tends to take on a scary appearance (Vereshchagin 1995: 153). It can be either black and fearsome or as grey as a badger. It has a long beard and wears a white hat with a hole on its top so one can see the hairless crown of its head (Vereshchagin 1996: 89). It is also believed to have long equine ears, wear a long traditional coat called $a z^{\prime} a m$ or sukman and, unlike the leshiy of Russian belief (Levkiyevskaya 2004: 105), it is always girded with a black or multicolour woven belt (FE-1980:

Illustration 1. Picture by Valentin Belykh. N’ulesmurt (Forest man).

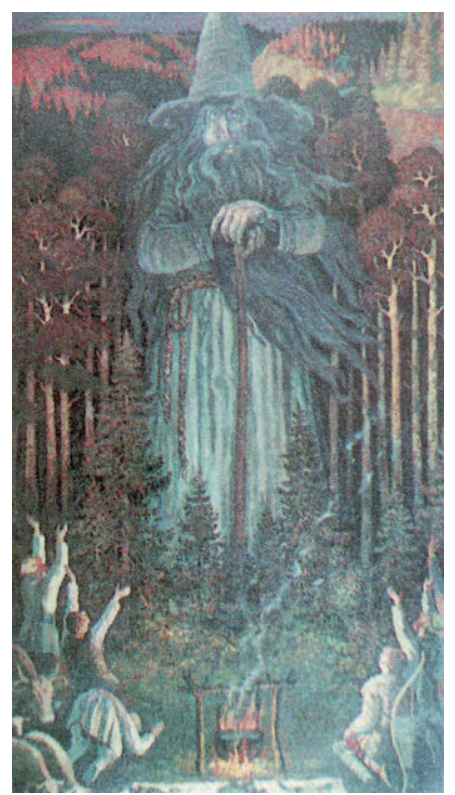


Selty district of Udmurtia. NB. 3. Pp. 94-96), which obviously serves as evidence of its greater proximity to the domesticated space, which is not typical of other spirits. It is believed to hold sway over other forest inhabitants, for example animals and birds can move anywhere it orders them to go. Sometimes n'ulesmurt gambles forest animals away and relocates their herds to other n'ulesmurts that inhabit neighbouring forests. It becomes extremely angry with hunters who laugh at a dead bear; in order to punish blasphemers it breathes life into the bear (Vereshchagin 1995: 94). Its whistle and shout can easily animate animals and birds killed by hunters (Vereshchagin 2001: 47, 48-49).

One of its distinguishing features, and a constant motif in Udmurt folk tales, is its ability to move rapidly: it can walk and run like the wind and fly in a whirlwind (Vereshchagin 1996: 175). A man raised by n'ulesmurt high in the sky exclaims that his hat has fallen down, and the forest spirit immediately replies to him that his hat is already seven or forty versts away.

The initially syncretic notion of n'ulesmurt as forest and wind deity emphasises that it is equivalent and identical to the spirit tölperi (derived from words töl 'wind' and peri 'spirit'). The last component of its name is of eastern origin, and apparently implies that the spirit of the wind is of more recent origin. Its distinctive characteristics overlap with those of n'ulesmurt, for example, they both hoot with laughter, and their appearances are generally accompanied by loud noise so that trees start to sway with the wind. While in the past they were split, today the images of these mythological beings have tended to merge (Volkova 1997: 56-57).

According to folk tales, God presented people with the wind to prevent the sunlight from being blocked by cobwebs, but the wind submitted to n'ulesmurt and began to blow too strongly, thus causing a whirlwind (Vereshchagin 1996: 130). The Udmurts living in the Glazov uyezd, Vyatka governorate (today's northern districts of the Udmurt Republic) believed that debris in the woods caused by terrible storms are the road followed by a n'ulesmurt wedding 
procession (n'ulesmurt koshkiz s'uane[n]) (Pervukhin 1888 (1): 77). The belief that wood debris occur in places where nyulesmurt moves around has persisted to the present day. The Udmurt try to keep away from these sites in order to avoid trouble or bad luck, such as becoming suddenly paralysed.

The whirlwind can stop if a person utters the magic formula Tirepurte bordam! ((I have) my axe and knife by me!) or throws a knife or axe at it. In Udmurt mythological narratives tölperi itself or its father can unexpectedly appear in front of people in the guise of an elderly man. It demonstrates the weapon thrown into the whirlwind and rebukes them for attempting to kill it. In another story, a hunter throws a knife into a whirlwind, but then suffers the consequences when tölperi unroofs his house and household buildings. Later tölperi explains that the hunter stabbed it with a knife when it was driving hares into the hunter's trap (Bogaevskiy 1890: 6364). During a raging storm the northern Udmurt would go outside and shout, "Grandfather [the forest man], do not harm me!", and the family would expect the house buildings to be safe from the storm.

Like other mythological beings, n'ulesmurt is an ambivalent spirit, it can both do considerable harm and also bring substantial benefit. It is always hostile towards people who misbehave and break accepted norms, in which case it takes them over the forest or tickles them to death. It greatly dislikes being mentioned as l'eshak (derived from the Russian word leshiy), which demonstrates a lack of respect. N'ulesmurt is scared stiff of dogs or even a small piece of dog fur. There is a belief that it is more frightened of a dog than of a cross (Pervukhin 1888 (1): 84), so, before going hunting or forest harvesting, the Udmurt sew a piece of dog fur into their outerwear or wind it into their onuchi (cloth wrapped around the feet inside the boots) to protect themselves, and sew it round their gunpowder pouches. In folk tales the forest spirits cannot harm people until they take off their dog fur mittens (Pervukhin 1888 (1): 81-82). 
N'ulesmurt is merciful to people if they offer it a propitiatory sacrifice (a black duck, goose, black cock, or hazel hen) (Pervukhin 1888 (1): 77). In these cases, it assists in hunting wild animals, treasure hunting and finding lost cattle. If a pack of wolves came down to a village, the locals vowed to offer two foals and ducks as sacrifices to n'ulesmurt. The sacrifice was invariably performed only by men in the forest.

According to folk belief, n'ulesmurt often acts as a conveyor of supernatural knowledge: a trainee is carried over the forest by someone invisible (FWM: Yakshur-Bod'ya district of Udmurtia, 1996) and as a result gains supernatural knowledge and the ability to use magic and witchcraft. As a token of the acquired supernatural power, they are awarded a white scarf and an antique silver coin (Pervukhin 1888 (1): 85). Those who are not capable of mastering the supernatural knowledge are believed to become insane.

N'ulesmurt is an ardent devotee of Udmurt "pagan" religious beliefs. It takes a trainee over the forest and indicates the improprieties the Udmurt are committing (for example, disregard for the customs of ancestors, wearing coloured clothes instead of white garments, violating taboos, etc.). However, this does not prevent it from attending church services, which it leaves before the cherubic hymn (Vereshchagin 1997: 209-210). According to contemporary data, only people with magical powers (tuno, pel'l'as'kis') are capable of seeing it in the church. It generally appears in the guise of a man wearing black clothes and turns a somersault before leaving the church (FWM: Yakshur-Bod'ya district of Udmurtia, 2006). With the spread of Christianity, n'ulesmurt merges with the image of Saint Nicholas.

In the past, the northern Udmurts sought n'ulesmurt's protection practically every week. On Tuesdays, Thursdays or Sundays, they enacted the rite s'iyon potton, 'taking food out' (Vereshchagin 1998: 212-213). A housemistress baked saltless pancakes of unleavened bread and wrapped them into a piece of white canvas, which the housemaster took away to a field fence where n'ulesmurt 
was believed to walk. While performing the rite, certain rules are compulsory, for example, it was prohibited to talk to passers-by or to meet people crossing a road. The pancakes were placed on a tree stump or on a narrow shelf specially made of small branches as well as being placed between fence sticks. Afterwards, the man made three deep bows but without crossing himself. Birds flocking to the sacrifice were a token of n'ulesmurt's favour.

The custom of offering a sacrifice to n'ulesmurt prior to the gardening season has survived to this day. In order to get a rich harvest the housemistress bakes pancakes out of egg yolks and puts the pancakes and a piece of bread on a fence post or a tree fork. Some Udmurt still believe that people who maintain contact with the n'ulesmurt produce good yields (FWM: Yakshur-Bod'ya district of Udmurtia, 2006).

During calendar holidays the Udmurt worshipped not only their supreme gods (Inmar, Kyldys'in, Kuaz), but also n'ulesmurt. In addition, there were special days to worship and offer sacrifices to the forest spirit, for example, n'ulesmurt n'iman'n'ik ('n'ulesmurt's day'), in which a red bull was slaughtered on the third or fourth day after Trinity Sunday in honour of n'ulesmurt (Pervukhin 1888 (2): $26,68)$. In Udmurt prayers n'ulesmurt is mentioned along with the triad of supreme gods and the guardian spirit Vorshud (Pervukhin 1888 (3): 23). The Udmurt asked it to calm storms, to divert whirlwinds and prevent crops being damaged by storms. N'ulesmurt was also supposed to protect the livestock allowed to graze in the forest (Pervukhin 1888 (3): 23). If the cattle went astray, an extremely large bast shoe was hung on a spruce as a propitiatory sacrifice to n'ulesmurt (Bogaevskiy 1890: 67). The symbolism of the bast and the custom performed are similar to those in Russian indigenous culture (Vinogradova, Tolstaya 2004: 81).

According to folk narratives and mythological texts recorded recently in different local traditions, beliefs about n'ulesmurt are still widely held, although they are definitely undergoing transformation. Thus, in the late $19^{\text {th }}$ century n'ulesmurt was followed by 
a wolf (Vereshchagin 2001: 44) and was believed to be extremely scared of dogs. Currently it is accompanied by a pack of dogs, the colours of which emphasise their otherworld nature (grey, black and spotted): “...a grey, a black and a white-necked dog suddenly appeared. Someone like a human followed them, he had black hair and a black beard, he was wearing sukman and was girded with a belt with red, blue, and green stripes fringed with tassels. A rifle was strapped to his back" (FE - 1991: Sharkan district of Udmurtia. NB. 4. Pp. 15-16). When describing the forest man's appearance, respondents provide specific details that correspond to folk beliefs about mythological beings: "We, two girls, were going on a cart pulled by a bull. I feel that the forest man was walking along. He had a white stick, a beard, a pointed hat, and a black belt" (FE - 1980: Selty district of Udmurtia. NB. 3. Pp. 94-96.). Contemporary folk narratives also emphasise the idea that people who are known to have supernatural knowledge can easily establish communication with the forest spirit: "In my childhood we went cranberry picking with an elderly man. We knew he could talk to the forest spirit. We sat down to have a rest and the old man said: "You guys, do not be afraid if I invite someone”. He and an elderly man sat down some distance from us and spoke some strange language. It lasted about one hour. Then the forest man stood up and left, and a fierce wind blew up. Trees bent to the ground" (FE - 1991: Sharkan district of Udmurtia. NB. 4. Pp. 15-16).

N'ulesmurt performs didactic functions as before, but today it is considered to be more responsible for the environment: "My father used to tell me [this story]. He said he was harrowing near the forest. He found a crow's nest and took it. He only went two or three steps into the forest and got lost. He said he was walking around the forest and coming to the same place. Then he saw a grey-bearded elder sitting on a tree stump and counting money. "Why are you walking around?" the old man asked. "I went astray and cannot get out of the forest", he said. "And why have you taken the crow's nest?" the old man asked. "I don't know", my father said. "Never 
do it again". And then suddenly, he said, both the tree stump and the elder disappeared. And my father found himself at a fence. He had met the forest man then" (FE - 1988: Igra district of Udmurtia. NB. 1. Pp. 118-119).

Contemporary beliefs about n'ulesmurt are dependent on multiple traditional elements (the interrelationship between pre-Christian and Christian beliefs, interethnic relations, the influence of modern mass media and new information technologies), but despite the fact that current ideas about this mythological character are fragmentary and incomplete, the spirit's dominant traits have been preserved in complete agreement with the traditional belief system. The following example amply illustrates the proposition. A woman, who falls asleep in the forest at noon, is awoken by a creature that an informant refers to as töd'y kylchin (white, i.e. holy, tutelar deity) only because of its key attribute, i.e. its white clothes, and emphasises that white clothes are a good omen, whereas black is an evil one. Moreover, it is perfectly obvious that the supernatural agent mentioned is n'ulesmurt as it retains distinctive features (it is tall, it wears a soldier's coat, dances, and wakes a person who goes to sleep in the forest) (Shutova et al. 2009: 207).

\section{Palesmurt ('half man')}

Another forest spirit in the Udmurt mythology is palesmurt ('half man') / palkuas ('one ski'). Folklore and ethnographic materials demonstrate that it ranks second among all the other mythological beings inhabiting woodlands considering the prevalence of beliefs about it and the frequency of mentions in Udmurt fairy tale and non-fairy tale prose.

Folk beliefs about palesmurt vary in different regions of the Udmurt Republic. Most of the information was collected from the Udmurt living in the northern and central districts, which are covered by forest. According to the data recorded there palesmurt has 
a highly specific appearance, its main distinguishing feature is halfness, i.e. it is represented as an anthropomorphic being, dissected along the spine. Folklore data provide a more detailed description: palesmurt is believed to move by jumping on one foot; it is supposed to have only one arm, one eye and one ear as its head is half-split, but its nose and mouth are complete (Pervukhin 1888 (1): 88); and one can see all its internal organs (Vereshchagin 2000: 215), in particular its lungs and liver (FE - 1982: Yakshur-Bod'ya district of Udmurtia. NB. 5, p. 68) which fall out of its body (RA UIHLL: F. 762. NB. 11, p. 5). Implicit information about its unusual physical appearance is given by describing its ski tracks: "They say, when it travels across the snow, it leaves one ski track" (FDE - 1988: Igra district of Udmurtia. NB. 2, Pp. 39-40). The Udmurt living in the central part of Udmurtia believe that palesmurt has a whole body, with one transparent half (Kel'makov 1981: 118). As a rule, its gender identity is not established, although the evidence collected in Yakshur-Bod'ya district demonstrates that palesmurt is a male being (FE-1982: Yakshur-Bod'ya district of Udmurtia. NB. 5, P. 68).

According to our current studies, the Udmurt inhabiting the southern regions with low forest cover either have never heard of palesmurt, or believe it to be a giant monster: "They say that once palesmurt bumped into the gates. They say it is extremely big - as tall as a haystack" (FE - 1984: Alnashi district of Udmurtia. NB. 3, P. 48); "My maternal grandmother used to tell me that once she was returning from haymaking at twilight, it was almost dark, and she was walking around the place where people could see or hear weird things. She said she was running along the road, and it [palesmurt] was following her behind the woodline. It followed her to the bridge but it could not cross the river. She said, it was extremely tall" (FWM: Alnashi district of Udmurtia, 2015). In the southern Udmurt folk tales about ancient settlers, palesmurt is associated with the mythical giant alangasar. "In the old days our land was covered by dark, impenetrable forests. Those forests were inhabited by palesmurts called alangasar. They were as tall as fir trees, they 
could almost reach the sky, they were half-bodied, and their insides fell out of their body" (Atamanov 1981: 55). This plotline develops alongside another storyline about giants who turn into legendary warrior heroes and clan leaders (Vladykina 1998: 169-239).

Folk beliefs about half-beings are worldwide spread: they are typical of the traditional cultures of other indigenous peoples inhabiting Eurasia, Africa, Australia, Oceania, and North and South America (Berezkin 2011: 155-156). However there is a significant difference between those beliefs about half-creatures. In the Central part of the Old World (Europe, North Africa and Asia, with the axis passing through the Mediterranean and across Indonesia) they are presented as positive characters in fairy tales. They are ultimately able to restore their physical integrity in the final part of narratives. Whereas in the southern (south of the Sahara) and northern parts of the Old World (a large part of Eurasia from the Baltic Sea to the Pacific Ocean, and South-East Asia) mythic halfbeings are generally presented as dangerous, and hostile creatures of the underworld (Berezkin 2011: 155-156). In the Evenki epos, for example, malevolent spirits of the Lower world - avakhi, ogengaare described as huge creatures whose appearance can easily make people scared of them: they have one huge iron leg, one arm in the middle of their chest, one eye in the middle of the forehead, and one ear at the back of the head (Martazova 2009: 143).

Udmurt beliefs and folklore texts confirm the above observations, made by Yuriy Berezkin: unlike n'ulesmurt, palesmurt is always considered hostile towards people, it can frighten or tickle them to death, and contacts with it are believed to foreshadow misfortune. A vast number of memorates (bylichka) concerning experiences of encountering palesmurt finish by breaking tragic news. "We were harrowing near small ravine called Izishurn'uk, I was about 12 . We heard somebody crying 'oh-oh-ay'. The cry was heard closer and closer. [My friend called] Zoya said to me, 'Fira, let's go back home'. So we came back home around lunchtime. We met a woman called Afinia. She said, 'You should have answered 
with "last year's aspen leaves [go] down the river". She made us return to that place. If you don't answer, the palesmurt, it will reach you and tickle you to death. So we went to that place again, with Afinia. She went into the forest and either said something or did not, but immediately it became quiet there. We finished harrowing and went back home, trying to predict who was going to have trouble. Zoya came into the yard - her mother had died in the yard. An abscess turned out to have developed on her chest and it burst. The palesmurt yelled terribly. We both heard it yelling" (Tronina 2007: 138).

A palesmurt possesses characteristic features typical of demonic beings: people encounter it only in the forest, which is supposed to be a territory belonging to the otherworld, and this unexpected meeting generally comes at twilight or at noon. Moreover, not only does it emerge suddenly, it also disappears instantaneously (Pervukhin 1888 (1): 88-89). Before it becomes visible, one can hear some strange sounds, noise, screams, crying, or a person can even be called by name. According to folklore texts, its speech is inarticulate and poorly developed and mainly consists of interjections and exclamations.

People are supposed to follow a set of rules in order to protect themselves in the forest. For example, it is generally accepted that you should not shout for any reason, make noise or respond to any kind of cries, exclamations or calls, otherwise you may encounter demonic beings, including palesmurt. If one meets a palesmurt anyway, one has to strip naked (FE - 1982: Yakshur-Bod'ya district of Udmurtia. NB. 2, Pp. 50-51) or wear shoes on the wrong feet (FE - 1985: Alnashi district of Udmurtia. NB. 1, P. 57). These actions are aimed at removing the evidence of belonging to the human world and obtaining the characteristic features of the other world. One can also escape death by climbing over a village fence (FWM: Igra district of Udmurtia, 2005), which is interpreted as the boundary between civilised, domesticated space, built by men and their activities, and wild and hostile space where malevolent 
spirits live. Palesmurt cannot see and harm people hiding behind a mountain ash or rowan tree, which are believed to have apotropaic power and can protect people from malicious agents (RA - UIHLL: F. 519. P. 312). If a palesmurt asks a traveller where it should go, or asks the traveller where he or she is going, they are expected to answer briefly 'downriver', or just point towards the mouth of a river. If a palesmurt is sent to the source of a river, it can return and tickle the person to death (Atamanov 1981: 55). However, the contemporary data collected from young Udmurt demonstrate that folk beliefs are being transformed: "They say if you happen to meet a palesmurt, you should direct it upriver!" (Tronina 2007: 82). Other possible responses to avoid the negative effects of contact with this supernatural being are: "Last year's aspen leaves go down the river!" or an extremely brief reply, a truncated version of this, "Last year's" (Tronina 2007: 138). Sending malevolent spirits downriver is a well-known motif in Udmurt mythology. The river is regarded as a specific route to the underworld in most indigenous cultures (Vinogradova 2009: 416). According to the Udmurt, the river connects the human world with the upper and lower worlds (Vladykin 1994: 75; Napol'skikh 1992). These beliefs are reflected in, for example, Udmurt calendar rites (Vladykina, Glukhova 2011: 144) and healing rituals (Panina 2014: 74-76).

As far back as the late $19^{\text {th }}$ century Nikolai Pervukhin mentioned that folk beliefs about palesmurt were consigned to oblivion as they had been gradually disappearing among the Udmurt inhabiting the Glazov Uyezd in Vyatka Governorate (today the northern districts of Udmurtia) due to the considerable influence of local Russian folk culture (Pervukhin 1888 (1): 89). Contemporary field studies confirm this situation in the north-western districts (for instance, Krasnogorskoye and Yukamenskiy districts) where interviewees reported that today it is almost impossible to encounter palesmurt because of the radical change that has occurred recently. Forests have become scarce while the number of motor vehicles, such as tractors, conversely, has dramatically increased. Neverthe- 
less, the archival materials of the Institute of Udmurt Philology, Finno-Ugric Studies and Journalism of the Udmurt State University (Izhevsk, Russia), and contemporary field studies amply demonstrate that folk beliefs about palesmurt have successfully persisted down the centuries in some parts of the Udmurt Republic (for example, Igra, Yakshur-Bod'ya, and Debessy districts). People still tell stories about unexpected and undesirable meetings with this forest demon. Field studies clearly demonstrate that beliefs about mythological beings are gradually changing, a transformation process that generally occurs among the young.

\section{Obyda ('forest woman')}

Although obyda is much less famous than the forest beings analysed above, it is of great scientific interest for several reasons. First, despite diverse and valuable research into Udmurt mythology and folk belief, obyda has not thus far been a subject of intensive study, either by folklorists or by ethnographers. Researchers either mention it without going into detail or provide extremely fragmentary information. The only exception is a recent article by Tatiana Vladykina titled "The Bee in Udmurt Mythoritual Practice and Folklore", wherein the obyda is considered a protector of bees and a helper in wild-hive beekeeping (Vladykina 2016: 149-150). Secondly, there is a marked trend towards promoting the image of obyda in contemporary pop culture. For example, in Tol Babay's residence, in Sharkan, one of the most popular winter tourist destinations in the Udmurt Republic, visitors are entertained not only by the famous New Year characters Tol Babay ("Winter grandfather", similar to Father Christmas) and Lymynyl ("Snow maiden'), but also by an obyda that resembles the baba yaga from Russian fairy tales. The Centre of Udmurt Culture, located in the village of Lyuk in Balezino district, organises visits to a local spring, and there, the participants meet an obyda introduced as 
the spring keeper. Another example, a museum guide in the guise of obyda conducts excursions for children in Glazov Museum of Local Lore (Nelidova 2008); in kindergartens during art classes, obyda is presented as a beautiful and gracious lady wearing a traditional Udmurt dress (Alekseeva 2016). These examples clearly demonstrate that contemporary ideas of obyda vary radically. On the one hand, this forest spirit is believed to be similar to Russian baba yaga or kikimora, i.e. an ugly tousle-haired woman wearing ragged clothes, while on the other hand it is presented as a pretty woman. In view of the current situation, the following questions arise: who is obyda according to traditional Udmurt folk beliefs, and what factors underlie the modern interpretations of its image? When conducting the research we rely both on textual and on linguistic data to answer these questions.

The earliest mention of obyda is due to Russian ethnographer of German origin Johann G. Georgi in the $18^{\text {th }}$ century. He wrote briefly about forest beings called Palas murt (half-man), and about Alida (leshiy), which had only one leg, turned backward, one big eye and one breast, which was so large that it could suffocate people when it was pressed into their mouths (Georgi 2007: 96). This information requires some clarification: firstly, as the researcher did not speak Udmurt, he was not quite accurate in writing the names of the mythological characters - palesmurt and obyda respectively. Secondly, their brief description is a sort of summary of features that characterise both beings, which makes the information rather ambiguous; in fact, the human-like half-creature with one leg, arm and eye is palesmurt, while obyda, according to folk belief, is a forest female creature with feet turned backward and huge saggy breasts, which it threw over its shoulders. It is noteworthy that mammary hypertrophy is one of the characteristic features of female demonic characters. Mythological beliefs about shaggy female creatures with overly large saggy breasts are widespread in traditional cultures of Eurasian peoples. They are to be found in the mythology of the Turkic peoples (Dyrenkova 2012: 231), for example, of the Bashkir 


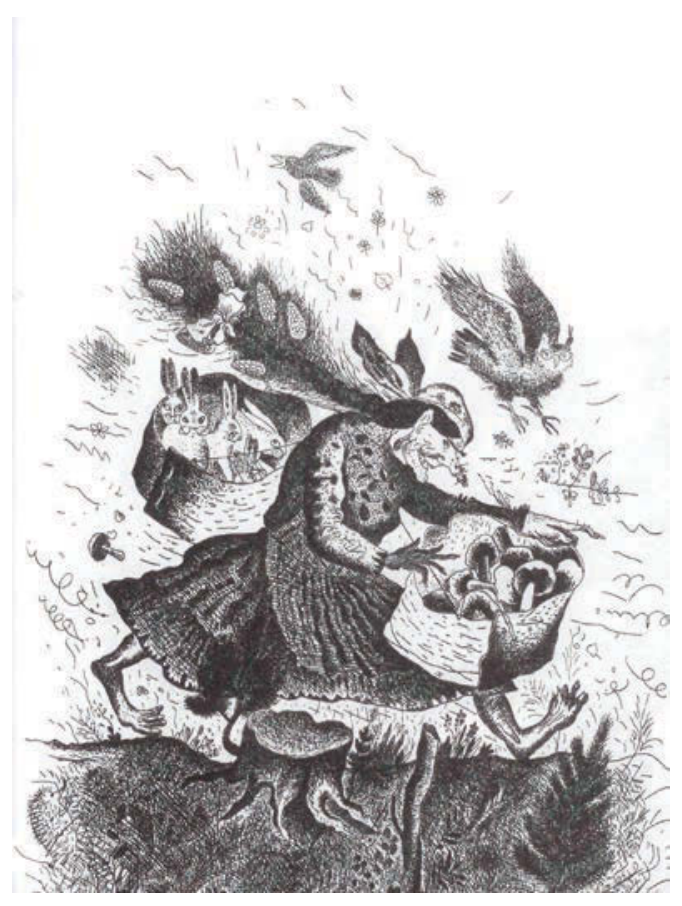

Illustration 2. Picture by Mensadyk Garipov. Obyda (Forest woman).

(albasty, shurale) (Rudenko 2006: 271; Khisamitdinova 2016 : 108, 218), the Altaians and Teleuts (almis) (Dyrenkova 2012: 235); in the folklore of peoples inhabiting the Caucasus (Shemshedinov 1910: 152), as well as in Slavic (boginka, rusalka, lisunka) and FinnoUgric traditions (ovda, vir'-ava) (Afanas"yev 1868: 343; Holmberg 1927: 438-439; Zelenin 1995: 213; Petrukhin 2005: 321; Toydybekova 2007: 176-178). Feet turned backward as an abnormal characteristic is also considered a distinctive attribute of otherworldly beings, for instance this feature is typical of demonic characters in the mythology of the indigenous peoples of the Volga-Ural region, such as the Mari ovda (Holmberg 1927: 183) and Bashkir yarymtyk (Khisamitdinova 2010: 382). These features are particular manifestations of basic semantic binary oppositions which are characteristic of an archaic worldview (human - nonhuman, us - them). There have been suggestions that Mari beliefs about ovda are based on historical facts about an ancient indigenous people inhabiting the territory between the Volga and the Vyatka Rivers in approximately the $10^{\text {th }}-11^{\text {th }}$ centuries (Aktsorin 1967; Toydybekova 2007: 178), but this theory seems unlikely. 
Illustration 3. Picture by Vladimir Nagovitsyn, Obyda (The forest woman).

During the first stage of the research process we selected a number of texts about this mythological character and discovered that there is a quite scant collection of Udmurt folk beliefs and narratives about obyda. we found data only in the Folklore Archive of the Udmurt Institute of

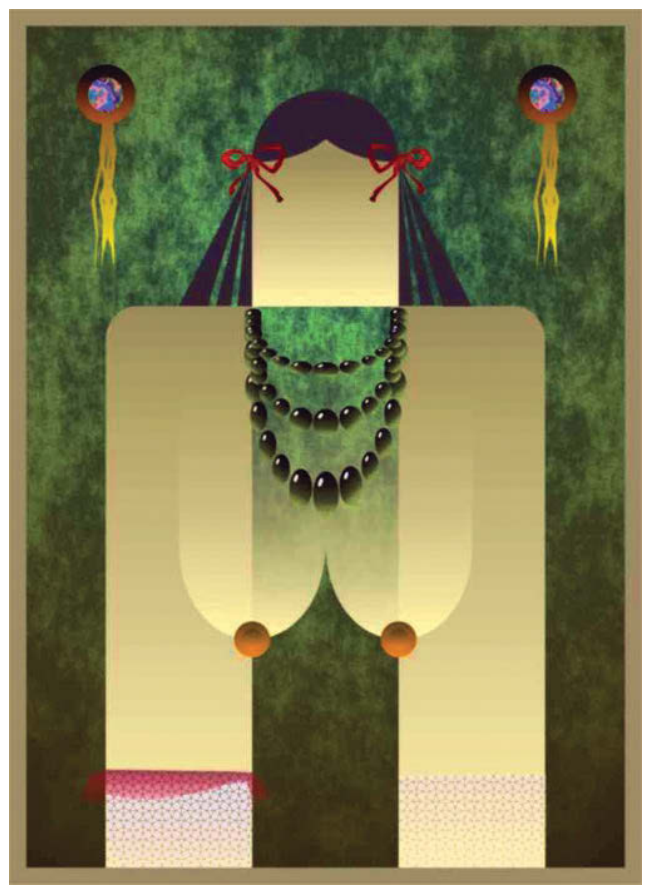
History, Language and Literature (Izhevsk) and in some published collections of Udmurt folklore texts (Gavrilov 1880; Wichmann 1901 (1), 1901 (2); Udmurtskiye narodnyye skazki 1948; Udmurt kalyk vyzhykyl"yos 1954; Sto skazok udmurtskogo naroda 1960; Udmurtskiye narodnyye skazki 1976). However, further analysis showed that the actual number of folklore texts about obyda is far less than the total number found, because one and the same folk story 'migrated' from one collection to another, often with no reference to the original source. Moreover, even in those books where compilers provide a commentary on the texts, the original is sometimes given incorrectly. For example, two out of three texts about obyda from the collection of Udmurt fairy tales (Sto skazok udmurtskogo naroda 1960) published in Russian contain false information about their origin. In fact, the fairy tales "The man and obyda" and "The soldier and obyda" are translated 
versions of folklore texts from one of Yrjö Wichmann's works (Wichmann 1901 (1): 56-57, 60-61), and not from Vyacheslav Gorbushin's collections, as the compiler Nadezhda Kralina states (Sto skazok udmurtskogo naroda 1960: 296). The Udmurt tale "Obyda the Crone" was also republished with some revisions providing no information on its source (Udmurt kalyk vyzhykyl"yos 1954: 62-63), that is "Folklore Texts, Rituals and Beliefs of the Votyaks from Kazan and Vyatka governorates", which was originally published in 1880 (Gavrilov 1880: 58-59).

The found originals have allowed us to clarify crucially important information, specifically when and where those texts were collected. All of them turned out to be recorded outside the Udmurt Republic in the late $19^{\text {th }}$ century: Yrjö Wichmann conducted field research in Bol'shoy Karlygan, village located in the Mari-Turek district of the Mari El Republic, while Boris Gavrilov recorded his fairy tale in the village of Tsip"ya, in the Baltasi district of Tatarstan, which borders Mari-Turek district. Thus, the researchers interviewed a group of local Udmurt who had direct contact with representatives of other ethnic groups, i.e. the Mari and Tatars. Moreover, in Mari folklore, ovda is one of the best-known mythological characters. Depending on local variations, ovda is believed to be an evil spirit (male or female). It can also be a forest female with saggy breasts that it throws crosswise over its shoulders, or a little owl that once used to be a man whom God turned into a bird as a penalty for some faults (Moisio, Saarinen 2008: 438-439), or a female creature with huge breasts, long hair and a shaggy coat (Bushkov 2014: 102). Researchers of Mari traditional culture note that folk stories about ovda are still widespread in rural communities (Toydybekova 2007: 176-178).

Linguists unanimously agree that the word obyda is not of Udmurt origin. Rifkat Akhmet'yanov suggests that the Mari words ovda/ovyda/abda, 'mischievious spirit', the Tatar atapa, 'unspecified spirit, devil', the Chuvash upăte, 'leshy, forest spirit', and the Udmurt obyda, 'forest female being' emerged in these 
languages as ancient Turkic borrowings from Buddhist literature deriving from the Sanskrit word amithaba, 'spirit of nature' (Akhmet'yanov 1981: 19). Adopting a phonetic criterion, the Finnish researcher Yrjö Wichmann suggested that the Udmurt word obyda came from the Chuvash language, and, moreover, the Mari words ovda and abda could also originate from Chuvash (Wichmann 1903, 89). This opinion is shared by Mikhail Fedotov, the author of the etymological dictionary of the Chuvash language (Fedotov 1996: 282). However, Fedor Gordeev puts forward a diametrically opposite hypothesis: he compared the Mari word ovda with the Ossetian lexemes ävdiiw and ävdew, 'demon, sorcerer', and suggested that ovda could originate from a ProtoOssetian (Sarmatian) source, and that the Chuvash word upăte/ opăte could come from Mari (Gordeev 1967: 201). However, other linguists refuted Gordeev's idea as it ignored a phonetic law: in the Mari language the Chuvash occlusive -p-/-b- transforms into the labiodental -v (Fedotov 1996: 282). Taking into account Yrjö Wichmann's conclusions, the Udmurt lexicologist Ivan Tarakanov considers that the word obyda is a Turkic-Bulgarian borrowing (Tarakanov 1982: 37). Nevertheless, this hypothesis raises some serious doubts. If it was a Bulgar loan word, it would be spoken in most Udmurt dialects. It presumably appeared in the Udmurt language as a result of interethnic contact with the Mari. According to the history of the vocalism of the first syllable in Udmurt dialects, to avoid an abundance of the vowel $o$ in the Udmurt vowel system the primary ${ }^{*} o$ had transformed to $u$ by the $15^{\text {th }}$ century (Kel'makov 1993: 17). This indicates that the word obyda could be borrowed long after this period, otherwise it would have changed into ubyda. Moreover, this lexeme occurs only in peripheral southern Udmurt dialects that are geographically distant from each other, namely in Shoshma dialect (spoken in Baltasi district of Tatarstan, Ivanovo district of the Republic of Mari El, and Malmyzh district of the Kirov Oblast) and in Krasnoufimsk dialect (Krasnoufimsk district of Sverdlovsk Oblast). In the former dialect it refers to 'monkey' or 
a 'forest mythological being', while in the latter it is used to describe a female mythological creature with huge saggy breasts (Nasibullin 1978: 130). This can be explained by the fact that the Shoshma and Krasnoufimsk local groups of Udmurt were considerably influenced by the Mari as they have been residing together for a prolonged time. It also provides indirect confirmation for the hypothesis that the Udmurt moved to the territory of modern Sverdlovsk Oblast with the Mari after the fall of Kazan in 1552 (Nasibullin 1978: 86). Having analysed the use of the particle ben (Udmurt ben 'yes', 'indeed') in the Udmurt dialects, Sergey Maksimov argues that the Krasnoufa Udmurt moved away from either the region where the Arsk (Trans-Vyatka) Udmurt currently reside, or from other southern Udmurt territories (Maksimov 2009: 73).

In Udmurt folklore texts obyda is presented as a forest creature who gives a human being assistance, and as a supernatural being similar to Russian baba yaga. The narratives provide neither general nor detailed description of the mythological being's appearance, but indirectly indicate that obyda comes from a large family. According to one folktale, obyda asks a man to make a wedding feast in the forest, specifically to bring the necessary tableware, to cook special dishes and to brew honey beer. The arrival of the wedding procession is accompanied by typical signs that indicate the presence of beings belonging to the demonic world: a fierce storm breaks out and blows trees down, so that the land starts to thrill. In Udmurt traditional culture the deafening noise and sudden changes in the weather are generally interpreted as evidence confirming the unexpected emergence of the forest master, n'ulesmurt.

Moreover, both n'ulesmurt and obyda are believed to bring good luck in wild-hive beekeeping. The Udmurt used to petition n'ulesmurt for good luck in beekeeping and hunting, alongside asking it to preserve grazing cattle and sheep in summer. In Udmurt folklore texts obyda shows a unique tree to a man, which he is to hollow out as a wild-hive. According to one story he makes three hives, each three arshins long (approximately 2 meters long) 
(Wichmann 1901 (1): 56), and according to another story nine wild hives (Wichmann 1901 (1): 59). The man follows obyda's advice and achieves phenomenal success: bees occupy all the hives because the tree that obyda found turns out to be a tree king (pispulen kunez). Udmurt texts about obyda's protection were also recorded, as mentioned above, in Mari-Turek district of the Mari El Republic, where there is widespread belief among the rural Mari that ovda can help people with the housework and on the farm, assist in keeping livestock, look after children and teach the Mari how to get money and hunt (Toydybekova 2007: 177).

Obyda's assistance is a dominant motif in the Udmurt folklore texts considered here. For example, one narrative starts with a man who wakes a sleeping obyda and thus saves it from a bear. As a token of gratitude it later helps him avoid long military service, presents him with a valid passport and returns him home (Wichmann 1901 (1): 60-61). In another story, obyda thanks a man for preparing a wedding feast and foretells that he will become fairly wealthy. Indeed, he largely succeeds in beekeeping and becomes a prosperous merchant (Wichmann 1901 (1): 56-57). This motif is also found in Mari traditional culture. For example, the Mari who lived in the village of Sernur in the Urzhum uyezd of Vyatka governorate believed that ovda often got its shaggy hair caught in a fence and generously rewarded people for setting it free (Bushkov 2014: 102). Mythological tales about ovda riding horses, often to death, all night long are widely spread among the Mari. In order to catch a mysterious rider the horse's back is smeared with tar. Ovda expresses gratitude to everyone who let her get off a horse, and curses those who decide to take its life (Toydybekova 2007: 177). Udmurt folk prose also comprises stories about mysterious night riders, but they generally refer to other mythological beings such as palesmurt and gidmurt (Udmurt: gidmurt, 'cattle barn spirit'). Folk tales about horse theft committed by demonic beings are widely distributed in the mythology of Turkic peoples as well, for example, in Tatar and Bashkir belief systems shurale and 
yarymtyk (Rudenko 2006: 269; Khisamitdinova 2016: 219) ride horses at night completely exhausting them.

In the Udmurt fairy tale "Obyda the Crone", obyda is presented as a devourer of people. In this regard it is functionally similar to other mythological characters such as kalmyk kyshno (literally: 'a Kalmyk woman'), kukri-baba (lit: 'a crooked old woman'), kuz'pin'omurt (lit: 'a being with long teeth') and iskalpydomurt (lit: 'a being with cow's legs'). According to the folk tale, a childless old man carves a son named Vanka (a diminutive of the Slavic name Ivan) from a log and sends him to plough. At that moment he is abducted by obyda who asks her daughter to roast the boy in a stove, but he cunningly deceives them and burns both of them. The narrative motifs of this tale partially correspond with East Slavic tale variants \#327A and 327C included in the Comparative Index of Plots: East Slavic Tales and international motifs G512.3.2 (Ogre burned in his own oven), and G512.3.2.1 (Ogre's wife (daughter) burned in his own oven) from Stith Thompson's Motif-Index of Folk-Literature (Thompson 1955-1958).

It is the Udmurt text's close similarity to East Slavic fairy tales that explains why obyda is almost identical to the Russian baba yaga in contemporary popular culture. The lack of detail on what obyda looks like and undeveloped ideas about this mythological character in the territory of Udmurtia contributed to the fact that it is now described as the Russian baba yaga. As regards the descriptions of obyda as a graceful girl wearing Udmurt traditional costume, they were probably influenced by folk tales in which obyda behaves in a kind and friendly way towards a human providing him with generous help.

The study shows that the motifs found in Udmurt folk tales about obyda are basically similar to those of Mari texts about ovda. However, unlike Mari folklore, in which ideas about ovda are well developed, Udmurt beliefs about obyda are not widespread. There are sparse text data recorded only in the late $19^{\text {th }}$ century from local groups of Udmurt living outside of Udmurtia and having 
direct contact with the Mari population. Since the middle of the 20th century, information about obyda has become available to the wider public due to the collections of Udmurt fairy tales published both in Udmurt and Russian.

\section{Abbreviations}

FWM - (Authors') fieldwork materials

F - file

$\mathrm{NB}$ - notebook

$\mathrm{P}$ - page

FE - Folklore expedition (Folklore Archive of the Institute of Udmurt Philology, Finno-Ugric Studies and Journalism of the Udmurt State University, Izhevsk, Russia)

RA UIHLL - Research Archive of the Udmurt Institute of History, Language and Literature, Udmurt Federal Research Centre of the Ural Branch of the Russian Academy of Sciences (Izhevsk, Russia)

FDE - Folklore and Dialect. Expedition (Folklore and Dialectal Archive of the Institute of Udmurt Philology, Finno-Ugric Studies and Journalism of the Udmurt State University, Izhevsk, Russia)

\section{References}

Afanas'yev, A. 1981. Poeticheskiye vozzreniya slavyan na prirodu. Opyt sravnitel'nogo izucheniya slavyanskikh predaniy $i$ verovaniy, $v$ svyazi s mificheskimi skazanyami drugikh rodstvennykh narodov [The Poetic Views of the Slavic People on Nature. Experience of Comparative Study of Slavic Legends, Belief, and Sayings in the Frame of Mythical Tales of Other Related Peoples]. II. Moscow: Gracheva i Komp.

Akhmet'yanov, R. 1981. Obshchaya leksika dukhovnoy kul'tury narodov Srednego Povolzh'ya [The General Vocabulary of the Spiritual Culture of the Peoples of the Middle Volga Region]. Moscow: Nauka.

Aktsorin, V. 1967. Etnogenez mariyskogo naroda po dannym fol'klora. Proizkhozhdeniye mariyskogo naroda [The Ethnogenesis of the Mari People According to Folklore. The Origin of the Mari People]. YoshkarOla: Mariyskoye knizhnoye izdatel'stvo, pp. 159-164.

Alekseeva, T. 2016. Obyda. Otkrytyy urok [Open Lesson]. https://openlesson.net/2561/ (accessed 26.09.2020). 
Atamanov, M. 1981. Grakhovskiye govory yuzhnoudmurtskogo narechiya. Materialy po udmurtskoy dialektologii:Obraztsy rechi [Grakhov Subdialect of the Southern Udmurt Dialect. Materials on Udmurt Dialectology: Speech Samples]. Izhevsk: Nauchno-issledovatel'skiy institut, pp. 45-96.

Barag, L., Berezovskiy, I., Kabashnikov, K., Novikov, N. 1979. Sravnitel'nyy ukazatel' syuzhetov: Vostochnoslavyanskaya skazka [Comparative Index of Plots: East Slavic Tales]. Leningrad: Nauka.

Berezkin, Y. 2011. Chetyre fol'klornykh motiva iz trekh epokh v istorii Filippin i Indonezii. Pilipinas muna! Filippiny prezhde vsego: K 80-letiyu Gennadiya Evgen'evicha Rachkova [Pilipinas Muna! Philippines First of All: On the $80^{\text {th }}$ Birthday of Gennady Rachkov]. Sankt-Petersburg: MAE RAN. Maklayevskiy sbornik 4, pp. 136-172.

Bogaevskiy, P. 1890. Ocherki religioznykh predstavleniy votyakov [Essays about the Religious Representations of the Votyak] VI. Etnograficheskoye obozreniye [Ethnographic Review]. Book VII. No. 4, pp. 42-70.

Bushkov, R. 2014. Zhernovoy kamen' [A Millstone]. Vestnik mariyskogo gosudarstvennogo universiteta [Mari State University Bulletin] 1, pp. 102-106.

Dyrenkova, N. 2012. Tyurki Sayano-Altaya. Stat'i i etnograficheskiye materialy [The Turks of Sayan-Altai. Articles and Ethnographic Materials]. Saint-Petersburg: Nauka.

Emel'yanov, A. 1921. Kurs po etnografii votyakov [A Course on Ethnography of the Votyaks]. Issue 3: Ostatki starinnykh verovaniy i obryadov $\mathrm{u}$ votyakov [Traces of Ancient Beliefs and Rites among the Votyak]. Kazan: Kazanskiy votskiy izdatel'skiy podotdel.

Fedotov, M. 1996. Etimologicheskiy slovar' chuvashskogo yazyka [Etymological Dictionary of the Chuvash Language]. Vol. 2. Cheboksary: Chuvashskiy gosudarstvennyy institut gumanitarnykh nauk.

Gavrilov, B. 1880. Proizvedeniya narodnoy slovesnosti, obryady i pover'ya votyakov Kazanskoy i Vyatskoy guberniy [Works on Folk Literature, Rituals and Beliefs of the Votyak of Kazan and Vyatka Governorates]. Kazan: Tipografiya A. A. Kokovinoy.

Georgi, J. G. 2007. Opisaniye vsekh obitayushchikh v Rossiyskom gosudarstve narodov: ikh zhiteyskikh obryadov, obyknoveniy, odezhd, zhilishch, uprazhneniy, zabav, veroispovedaniy $i$ drugikh dostopamyatnostey [Description of all the Peoples Living in the Russian State: Their Rituals, Habits, Costumes, Dwellings, Practices, Pastimes, Beliefs and Other Peculiarities]. Sankt-Petersburg: Russkaya simfoniya.

Gordeev, F. 1967. Baltiyskiye i iranskiye zaimstvovaniya $v$ mariyskom yazyke. Proiskhozhdeniye mariyskogo naroda [Baltic and Iranian Loanwords in Mari. The Origin of the Mari People]. Yoshkar-Ola: Mariyskoe knizhnoe izdatel'stvo, pp. 180-203. 
Holmberg, U. 1927. Finno-Ugric, Siberian. The Mythology of All Races. IV. Boston: Cooper Square Publishers.

Karpova, L. 2005. Srednechepetskiy dialekt udmurtskogo yazyka: Obraztsy rechi [The Middle Cheptsa Dialect of the Udmurt Language: Speech Samples] 9. Izhevsk: Udmurtskiy institut istorii, yazyka i literatury Uralskogo otdeleniya Rossiyskoy akademii nauk.

Kel'makov, V. 1981. Obraztsy udmurtskoy rechi: Severnoye narechiye $i$ sredinnyye govory [Samples of the Udmurt Speech. Northern Dialects and Central Subdialects]. Izhevsk: Udmurtia.

Kel'makov, V. 1993. Formirovaniye i razvitiye fonetiki udmurtskikh dialektov [Formation and Development of Phonetics of the Udmurt Dialects]. Izhevsk: Udmurtskiy universitet.

Khisamitdinova, F. 2010. Mifologicheskiy slovar' bashkirskogo yazyka [Mythological Dictionary of the Bashkir Language]. Moscow: Nauka.

Khisamitdinova, F. 2016. Mifologicheskaya leksika bashkirskogo yazyka (v etnolingvisticheskom osveshchenii) [Mythological Vocabulary of the Bashkir Language (in Ethnolinguistic Coverage]. Ufa: Udmurtskiy institut istorii, yazyka i literatury Uralskogo otdeleniya Rossiyskoy akademii nauk.

Kralina, N. 1960. Sto skazok udmurtskogo naroda [One Hundred Fairy Tales of the Udmurt People]. Izhevsk: Udmurtskoye knizhnoye izdatel'stvo.

Levkiyevskaya, E. 2004. Leshiy [The Forest Spirit]. In: Slavyanskiye dreunosti: Etnolinguisticheskiy slovar' [Slavic Antiquities: Ethnolinguistic Dictionary]. Vol. 3. Moscow: Mezhdunar. otnosheniya, pp. 104-109.

Maksimov, S. 2009. Kommentarii k karte. Chastitsa 'da' [Comments about a Map. The Particle "da"]. In: R. Nasibullin, S. Maksimov, V. Semenov et al. Dialektologicheskiy atlas udmurtskogo yazyka. Karty $i$ kommentarii [Dialectological Atlas of the Udmurt Language. Maps and Comments]. Izhevsk: NITS, pp. 69-73.

Martazova, O. 2009. Obrazy dukhov trekh mirov v evenkiyskom epose [The Characters of the Spirits of Three Worlds in the Evenki Epic]. In: T. Vladykina (ed.) Traditsionnaya kul'tura v izmenyayushchemsya mire [Traditional Culture in the Changing World]. Izhevsk: Udmurtskiy institut istorii, yazyka i literatury Uralskogo otdeleniya Rossiyskoy akademii nauk, pp. 137-145.

Moisio, A., Saarinen, S. 2008. Tscheremissisches Wörterbuch [Mari Dictionary]. Helsinki: Suomalais-Ugrilainen Seura.

Munkácsi, B. 1952. Volksbräuche und Volksdichtung der Wotjaken [Folk Customs and Folk Poetry of the Votyak]. Helsinki: Suomalais Ugrilainen Seura.

Napol'skikh, V. 1992. Proto-Uralic World Picture: A Reconstruction. In: Northern Religions and Shamanism. Ethnologica Uralica, 3. Budapest \& Helsinki: Akadémiai Kiadó; Suomalainen Kirjallisuuden Seura, pp. 3-20. 
Nasibullin, R. 1978. Nablyudeniya nad yazykom krasnoufimskikh udmurtov [Observations about the Languages of the Krasnoufa Udmurt]. In: $O$ dialektakh $i$ govorakh yuzhnoudmurtskogo narechiya [About Dialects and subdialects of the South Udmurt Language]. Izhevsk: Udmurtskiy institut istorii, yazyka i literatury Uralskogo otdeleniya Rossiyskoy akademii nauk, pp. 86-151.

Nelidova, N. 2008. Nechistaya sila k Svyatkam gotova [The Impure Force is Ready for Christmas]. In: Udmurtskaya Pravda [Udmurt Truth] No. 2. http://archive.udmpravda.ru/default/article?article=11992632 $30 \&$ issue $=24241 \&$ tape $=($ accessed 30.10 .2020$)$.

Panina, T.2014. Slovoiritualvnarodnoy meditsine udmurtov [Word and Ritual in the Udmurt's Folk Medicine]. Izhevsk: Udmurtskiy institut istorii, yazyka i literatury Uralskogo otdeleniya Rossiyskoy akademii nauk.

Panina, T. 2013. Ritual'noye zadabrivaniye dukha bolezni v kontekste udmurtskoy etnomeditsiny [Ritual Propitiation if the Illness Spirit in the Context of Udmurt Ethnomedicine]. Traditsionnaya kul'tura [Traditional Culture] 1, pp. 42-50.

Panina, T. 2017. Obrazy lesnykh dukhov v udmurtskoy mifologii i fol'klore. III: Obyda (lesnaya zhenshchina) [The Characters of the Forest Spirits in the Udmurt Mythology and Folklore. III: Obyda (Forest Female)]. In: Ezhegodnik finno-ugorskikh issledovaniy [Yearbook of Finno-Ugric Studies] 11 (2), pp. 53-66.

Pervukhin, N. 1888 (1). Eskizy predaniy $i$ byta inorodtsev Glazovskogo uyezda [Essays about the Legends and the Everyday Life of NonRussians of the Glazov District]. Eskiz 1: Drevnyaya religiya votyakov po ego sledam v sovremennykh predaniyakh [Essay 1: The Ancient Religion of the Votyak in Its Traces in Modern Traditions.]. Vyatka: Gubernskaya tipografiya.

Pervukhin, N. 1888 (2). Eskizy predaniy $i$ byta inorodtsev Glazovskogo uyezda [Essays about the Legends and the Everyday Life of Non-Russians of the Glazov District]. Eskiz 2: Idolozhertvennyy ritual drevnikh votyakov po ego sledam v rasskazakh starikov i v sovremennykh obryadakh [Essay 2: The Idol-Sacrificial Ritual of the Ancient Votyak in Its Traces in the Stories of Elder People and in Modern Rituals]. Vyatka: Gubernskaya tipografiya.

Pervukhin, N. 1888 (3). Eskizy predaniy i byta inorodtsev Glazovskogo uyezda [Essays about the Legends and the Everyday Life of NonRussians of the Glazov District]. Eskiz 3: Sledy yazycheskoy drevnosti v obraztsakh proizvedeniy ustnoy narodnoy poezii votyakov (liricheskikh i didakticheskikh) [Essay 3: Traces of Pagan Antiquity in Images of the (Lyrical and Didactical) Oral Folk Poetry of the Votyak]. Vyatka: Gubernskaya tipografiya.

Pervukhin, N. 1889. Eskizy predaniy i byta inorodtsev Glazovskogo uyezda [Essays about the Legends and the Everyday Life of Non-Russians of the 
Glazov District]. Eskiz 4: Sledy yazycheskoy drevnosti vobraztsakh ustnoy narodnoy poezii votyakov [Essay 4: Traces of Pagan Antiquity in Images of the Oral Folk Poetry of the Votyak]. Vyatka: Gubernskaya tipografiya.

Petrukhin, V. 2005. Mify finno-ugrov [Finno-Ugric Myths]. Moscow: Astrel'.

Rudenko, S. 2006. Bashkiry: Istoriko-etnograficheskiye ocherki [Bashkirs: Historical and Ethnographic Essays]. Ufa: Kitap.

Sadikov, R. 2008. Traditsionnyye religioznyye verovaniya i obryadnost' zakamskikh udmurtov (istoriya i sovremennyye tendentsii razvitiya). [Traditional Religious Beliefs and Rituals of the Eastern Udmurts (History and Modern Development Trends]. Ufa: Centr etnologicheskikh issledovaniy UNTs RAN.

Sadikov, R., Khafiz, K. 2010. Religioznyye verovaniya i obryady udmurtov Permskoy $i$ Ufimskoy gubernii $v$ nachale $X X$ veka: ekspeditsionnyye materialy Uno Holmberga [Religious Beliefs and Rituals of the Udmurts of the Perm and Ufa Governorates at the Beginning of the $20^{\text {th }}$ Century: Expedition Data by Uno Holmberg]. Ufa: Institut Etnologicheskikh issledovaniy UrO RAN.

Shemshedinov, A. 1910. Legendy i skazaniya kumykov [Legends and Tales of the Kumyks]. In: Etnograficheskoye obozreniye [Ethnographic Review], 1-2, pp. 137-155.

Shutova, N. 2001. Dokhristianskiye kul'tovye pamyatniki v udmurtskoy religioznoy traditsii: Opyt kompleksnogo issledovaniya [Pre-Christian Cult Monuments in the Udmurt Religious Tradition: An Experience of Comprehensive Research]. Izhevsk: Udmurtskiy institut istorii, yazyka i literatury Uralskogo otdeleniya Rossiyskoy akademii nauk.

Shutova, N., Kapitonov, V., Kirillova, L., Ostanina, T. 2009. Istoriko-kul'turnyy landshaft Kamsko-Vyatskogo regiona [Historical and Cultural landscape of the Kama-Vyatka Region]. Izhevsk: Udmurtskiy institut istorii, yazyka i literatury Uralskogo otdeleniya Rossiyskoy akademii nauk.

Smirnov, I. 1890. Votyaki: Istoriko-etnograficheskiy ocherk [The Votyak: Historical and Ethnographic Essay]. Kazan: Tipografiya Imperatorskago universiteta.

Tarakanov, I. 1982. Zaimstvovannaya leksika v udmurtskom yazyke (Udmurtsko-tyurkskiye yazykouye kontakty) [Borrowed Vocabulary in the Udmurt Language: (Udmurt-Turkic Language Contacts)]. Izhevsk: Udmurtia.

Thompson, S. 1955-1958. Motif-Index of Folk-Literature: A Classification of Narrative Elements in Folk Tales, Ballads, Myths, Fables, Medieval Romances, Exempla, Fabliaux, Jest Books and Local Legends. In 6 Vols. Bloomington: Indiana University Press. http://www.ruthenia. ru/folklore/thompson/g.htm (accessed 15.10.2020).

Toydybekova, L. 2007. Mariyskaya mifologiya [Mari Mythology]. YoshkarOla: MPIK. 
Tronina, I. 2007. Zhanry i obrazy udmurtskoy mifologicheskoy prozy [Genres and Images of the Udmurt Mythological Prose]. BA dissertation, scientific supervisor T. Vladykina. Izhevsk: Udmurtskiy gosudarstvennyy universitet.

Udmurtskiye narodnyye skazki [Udmurt Fairy Tales] 1948. Klabukov, A. (compiler). Izhevsk: Udmurtgosizdat.

Udmurt kalyk vyzhykyl"yos [Udmurt Fairy Tales] 1954. Klabukov, A. and Kralina, N. (compilers). Izhevsk: Udmurtskoye knizhnoye izdatel'stvo.

Udmurtskiye narodnyye skazki [Udmurt Fairy Tales] 1976. Kralina, N. (compiler). Izhevsk: Udmurtia.

Vereshchagin, G. 1995. Sobraniye sochineniy. Votyaki Sosnovskogo kraya [Collected Works: The Votyak of the Sosnovka Region]. Vol. I. Izhevsk: Udmurtskiy institut istorii, yazyka i literatury Uralskogo otdeleniya Rossiyskoy akademii nauk.

Vereshchagin, G. 1996. Sobraniye sochineniy: Votyaki Sarapul'skogo uyezda Vyatskoy gubernii [Collected Works: The Votyak from the Sarapul of the Vyatka Governorate]. Vol. 2. Izhevsk: Udmurtskiy institut istorii, yazyka i literatury Uralskogo otdeleniya Rossiyskoy akademii nauk.

Vereshchagin, G. 1998. Sobraniye sochineniy: Etnograficheskiye ocherki 1 [Collected Works: Ethnographic Essays 1]. Vol. 3. Izhevsk: Udmurtskiy institut istorii, yazyka i literatury Uralskogo otdeleniya Rossiyskoy akademii nauk.

Vereshchagin, G. 2000. Sobraniye sochineniy: Etnograficheskiye ocherki 2 [CollectedWorks: EthnographicEssays2]. Vol.4.Izhevsk:Udmurtskiyinstitut istorii, yazyka i literatury Uralskogo otdeleniya Rossiyskoy akademii nauk.

Vereshchagin, G. 2001. Sobranie sochineniy: Udmurtskiy fol'klor 1. Predaniya. Legendy. Pobyval'shchiny. Skazki. Basni. Poslovitsy. Pogovorki. Zagadki [Collected Works: Udmurt Folklore 1. Traditions. Legends. Prose. Fairy Tales. Proverbs. Sayings. Riddles]. Izhevsk: Udmurtskiy institut istorii, yazyka i literatury Uralskogo otdeleniya Rossiyskoy akademii nauk.

Vinogradova, L. 2009. Reka [The River]. Slavyanskiye drevnosti: Etnolinguisticheskiy slovar' [Slavic Antiquities: Ethnolinguistic Dictionary] 4. Moscow: Mezhdunar. Otnosheniya, pp. 416-419.

Vinogradova, L., Tolstaya, S. 2004. Lapti [The Bast-Shoes]. Slavyanskie drevnosti: Etnolingvisticheskiy slovar' [Slavic Antiquities: Ethnolinguistic Dictionary] Vol. 3, pp. 79-82.

Vladykin, V. 1994. Religiozno-mifologicheskaya kartina mira udmurtov [Udmurts' Religious and Mythological Worldview]. Izhevsk: Udmurtia.

Vladykina, T. 1998. Udmurtskiy fol'klor: problemy zhanrovoy evolyutsii $i$ sistematiki [Udmurt Folklore: Problems of Genre Evolution and Systematisation]. Izhevsk: Udmurtskiy institut istorii, yazyka i literatury Uralskogo otdeleniya Rossiyskoy akademii nauk. 
Vladykina, T. 2009. Obrazy lesnykh dukhov v udmurtskoy mifologii i fol'klore: I. N'ulesmurt (lesnoy chelovek/leshiy). [Images of Forest Spirits in Udmurt Mythology and Folklore I. N'ulesmurt (Forest Human / Forest Spirit)]. Traditsionnaya kul'tura v izmenyayushchemsya mire [Traditional Culture in the Changing World]. Izhevsk: Udmurtskiy institut istorii, yazyka i literatury Uralskogo otdeleniya Rossiyskoy akademii nauk, pp. 24-30.

Vladykina T., Glukhova G. 2011. Ar-god-bergan: Obryady i prazdniki udmurtskogo kalendarya [Year Circle: Rituals and Celebrations of the Udmurt Calendar]. Izhevsk: Udmurtskiy institut istorii, yazyka i literatury Uralskogo otdeleniya Rossiyskoy akademii nauk.

Vladykina, T., Panina, T. 2015. Obrazy lesnykh dukhov v udmurtskoy mifologii i fol'klore: II. Palesmurt (polovinchatyy chelovek) [Images of Forest Spirits in Udmurt Mythology and Folklore II. Palesmurt (HalfHuman Being)]. Ezhegodnik finno-ugorskikh issledovaniy [Yearbook of Finno-Ugric Studies] 4, pp. 59-67.

Vladykina, T. 2016. Pchela v fol'klore i miforitual'noy praktike udmurtov [The Bee in Folklore and Mythoritual Practice of the Udmurt]. Traditsionnaya kul'tura [Traditional Culture] 4, pp. 147-158.

Volkova, L. 1997. Veter kak mifologicheskiy personazh v mirovozzrenii udmurtov [Wind as a Mythological Character in the Worldview of the Udmurts]. Dukhovnaya kul'tura finno-ugorskikh narodov: istoriya i problemy razvitiya [The Spiritual Culture of the Finno-Ugric Peoples: History and Development Problems]. II. Glazov: GGPI, pp. 56-57.

Wichmann, Y. 1901 (1). Wotjakische Sprachproben II: Sprichwörter, Rätsel, Märchen, Sagen undErzählungen [Samples of VotyakLanguageII:Proverbs, Riddles, Tales, and Narratives]. Helsingfors: Finnish Literature Society.

Wichmann, Y. 1901 (2).Wotjakische Chrestomathie mit Glossar [A Votyak Chrestomathy with a Glossar]. Helsingfors: Finnish Literature Society.

Wichmann, Y. 1903. Die tschuwassischen Lehnwörter in den permischen Sprachen [The Chuvash Loanwords in the Permian Languages]. Helsingfors: Finnish Literature Society.

Yashin, D. 1974. Obshchiye motivy v skazkakh permskikh i tyurkoyazychnykh narodov [Common Motives in the Fairy Tales of the Permian and Turkic Peoples]. Fol'klor narodov RSFSR [Folklore of the Peoples of the RSFSR]. I. Ufa: Bashkirskiy Gosudarstvennyy universitet, pp. 63-68.

Zelenin, D. 1995. Izbrannyye trudy. Ocherki russkoy mifologii. Umershiye neestestvennoy smert'yu i rusalki [Selected Works. Essays on Russian Mythology. Dead by an Unnatural Death and Mermaids]. Moscow: Indrik. 


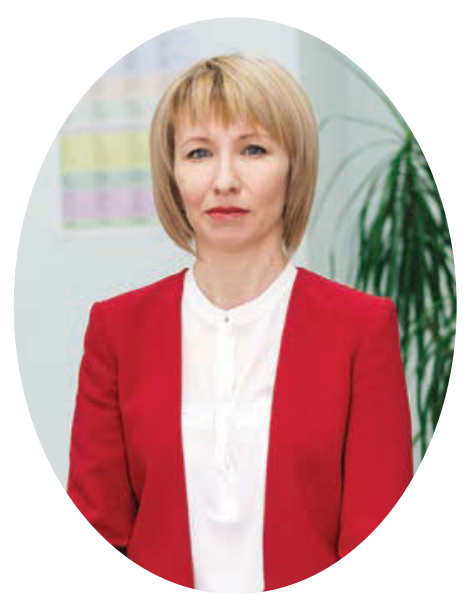

Tatiana Panina (PhD) is a researcher at the Department of Philological Studies, at the Udmurt Institute for Research in History, Language and Literature (Udmurt Federal Research Centre of the Ural Branch of the Russian Academy of Sciences). She is interested in traditional Udmurt culture, more precisely in folk medicine, incantation tradition and more recently dreams. Panina teaches English at the Izhevsk State Medical Academy. e-mail: tipanina@mail.ru

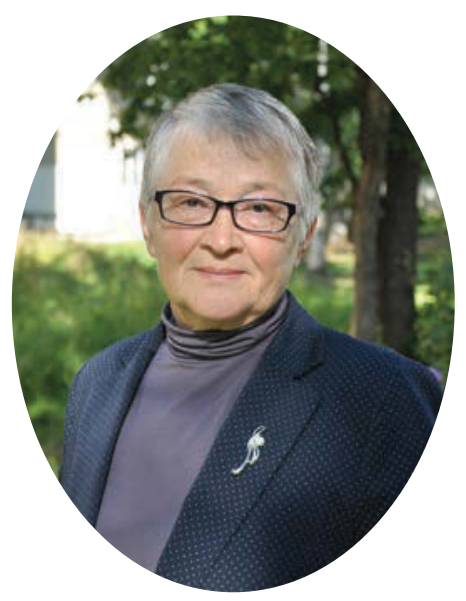

Tatiana Vladykina is ( $\mathrm{PhD}$ hab) a professor and leading researcher at the Udmurt Institute for Research in History, Language and Literature (Udmurt Federal Research Centre of the Ural Branch of the Russian Academy of Sciences). She has covered the range of topics in Udmurt folkloristics, especially mythology, specialising both in genre and in the treatment of the most important topics across genres.

e-mail: tgvladykina@mail.ru 